\title{
Selective feeding behavior of larval naked gobies Gobiosoma bosc and blennies Chasmodes bosquianus and Hypsoblennius hentzi: preferences for bivalve veligers
}

\author{
Juliana M. Harding* \\ Department of Fisheries Science, Virginia Institute of Marine Science, College of William and Mary, Gloucester Point, \\ Virginia 23062-1346, USA
}

\begin{abstract}
Naked gobies Gobiosoma bosc, striped blennies Chasmodes bosquianus, and feather blennies Hypsoblennius hentzi provide important intermediate links within the trophic structure of estuarine oyster reef communities. Predator-prey interactions between planktonic larvae of these fishes and larval eastern oysters Crassostrea virginica may influence recruitment success within oyster reef communities. These 3 species of oyster reef fish larvae were cultured from wild nests and used in multifactorial laboratory feeding experiments with larval oysters or hard clams Mercenaria mercenaria as well as wild plankton as prey items to determine the effects of predator age, predator concentration, and prey type on feeding selectivity of these fishes. Predator age significantly influenced feeding behavior of naked gobies and feather blennies. Predator concentration did not significantly effect feeding behavior for any of the 3 fish species. Prey type significantly affected feeding behavior of feather blennies and naked gobies. Naked gobies consumed bivalve veligers preferentially at all veliger concentrations. Feather blennies consumed veligers preferentially at concentrations as low as $12 \%$ of the available prey field. Striped blennies were less specialized in their feeding patterns but still consumed bivalve veligers preferentially at prey field concentrations as low as $11 \%$ veligers.
\end{abstract}

KEY WORDS: Larval fishes - Oyster reefs - Naked goby S Striped blenny · Feather blenny · Crassostrea virginica Predator-prey interactions - Selectivity · Chesson's alpha

\section{INTRODUCTION}

On the basis of numbers alone, oyster reef fish larvae are an important component of estuarine plankton: for example, naked goby Gobiosoma bosc larvae seasonally dominate Chesapeake Bay ichthyoplankton collections (Shenker et al. 1983, Cowan \& Birdsong 1985, Olney 1996). The local trophic effects of these planktonic predators are poorly understood. The connections between adult gobies, conspecific feather blennies Hypsoblennius hentzi and striped blennies Chasmodes bosquianus and living reefs created by eastern oysters Crassostrea virginica have long been acknowledged (e.g. Wells 1961, Dahlberg \& Conyers

·E-mail: jharding@vims.edu
1973). Adult fishes use the heterogeneous habitat created by the matrix of adult oyster shells for shelter as well as nesting and feeding grounds.

Growth and mortality patterns for larval fishes are strongly influenced by food availability and determine observed community recruitment relationships (Shepherd \& Cushing 1980, Houde 1989). Within oyster reef communities, planktonic fish larvae may be major predators on planktonic oyster larvae or 'veligers'. Temperate reef fishes and oysters spawn within the same approximate temporal or seasonal window, producing larvae that occur concurrently and undergo planktonic development followed by subsequent settlement and recruitment to the benthos. For larval fishes, abundant food supplies that are potentially available around and on oyster reefs increase growth 
rates and shorten the planktonic larval development period, reducing predation risks from pelagic invertebrate and vertebrate predators (Houde \& Schekter 1980, Hunter 1981). Reduction of time to settlement potentially increases recruitment of these benthic reef fishes (Shepherd \& Cushing 1980). Increased densities of benthic reef fishes provide more potential prey items for pelagic predators that use oyster reefs as feeding grounds and nursery areas.

Ichthyoplankton preference for bivalve veligers from the ambient prey field has been previously documented. Houde \& Lovdal (1984) and Govoni et al. (1986) reported strong preferences for veligers by several species of larval fishes in Biscayne Bay and the Gulf of Mexico. Olney (1996) described feeding behavior and preference for veligers by larval seaboard gobies Gobiosoma ginsburgi collected from the Chesapeake Bay plume. Checkley's (1982) laboratory experiments with herring Clupea harengus larvae using wild zooplankton as prey showed significant preferences for mollusc veligers.

Breitburg (1989, 1991) conducted field and laboratory studies with pre-settlement and settlement-stage (demersal) naked goby larvae to determine feeding incidence in relation to demersal schooling behavior and settlement. Gut contents from field caught demersal naked goby larvae were dominated by crustaceans ( $\mathrm{n}$ fishes = 22, Breitburg 1989; $\mathrm{n}$ fishes $=72$, Breitburg 1991). Laboratory experiments testing prey selectivity of planktonic goby or blenny larvae have not been described.

The objectives of this study were to test the effects of predator age, predator concentration, and prey type on feeding selectivity using bivalve veligers as the principal prey of cultured naked goby, striped blenny, and feather blenny larvae. A selected prey item is considered to be one whose proportional occurrence in gut contents is greater than its proportion in the available prey field.

\section{METHODS}

Predators. Larval fish culture: Larval gobies and blennies used in laboratory feeding experiments were cultured using nests that were collected from naturally occurring or artificially deployed oyster shell substrate in the Piankatank and York Rivers, Virginia, USA. Fish nests were identified by egg morphology (size, color) and the identity of the guarding parents. Nests were transported to the laboratory in individual plastic bags filled with river water. In the laboratory, nests were carefully placed in 0.51 beakers filled with a mixture of water from the field site and sand-filtered seawater. All beakers were maintained at $24^{\circ} \mathrm{C}$ under a $14 \mathrm{~h}$ light: $10 \mathrm{~h}$ dark regime; i.e. summer field conditions
As larvae hatched, they were moved to finger bowls filled with 1 l of sand-filtered seawater; larval densities were kept at approximately 150 per finger bowl. Larvae were fed rotifers Branchionus plicatilis several times daily from Day 0 post-hatching until approximately Day 8. During Days 8 to 18 , larval fishes were fed a mixture of rotifers and fresh $(<1 \mathrm{~d}$ old) Artemia sp. nauplii (Carolina Biological Supply, Inc.). The feeding mixture was gradually changed from 100 to $0 \%$ rotifers by Days 14 to 18 or when fishes began settlement. After $18 \mathrm{~d}$, or the initiation of settlement, fishes were transferred to aquaria filled with $30 \mathrm{l}$ of aerated, filtered seawater; fishes were maintained at densities $<100 \operatorname{tank}^{-1}$ and were fed 3 times daily with fresh Artemia sp. nauplii. After $21 \mathrm{~d}$, clean oyster shell was placed in each tank to provide shelter and daily feedings were reduced to 2 larger portions of 2 to $3 \mathrm{~d}$ old Artemia sp. nauplii.

Preliminary laboratory feeding experiments to determine gut residence time: The results of preliminary feeding experiments to determine gut residence time were used to establish the appropriate duration for subsequent larval feeding experiments. Experiments had to be long enough to allow prey items to pass into the gut but short enough to avoid defecation. Individual striped and feather blennies of various ages were allowed to feed in chambers containing high densities of prey items (either rotifers dyed with acridine orange or Artemia sp. nauplii) until guts were visibly full (approximately $2 \mathrm{~h}$ ). Individual fishes were then placed in chambers containing $0.15 \mathrm{l}$ of filtered seawater. Every $30 \mathrm{~min}$ for $5 \mathrm{~h}$, individual fishes were examined under a dissecting microscope to determine levels of gut fullness.

Multifactorial laboratory feeding experiments. Multifactorial feeding experiments were designed to test the effects of predator age and concentration on larval fish feeding and to evaluate prey selectivity with regard to bivalve veligers. To avoid potential habituation effects, cultured food organisms (rotifers or Artemia sp. nauplii) were never used as experimental prey items (Checkley 1982, Lindberg \& Doroshov 1986, Mills et al. 1987, Connaughton \& Epifanio 1993). Fishes used in any given experiment were usually from the same brood or nest. Experimental conditions were the same as fish culture conditions. Six to $8 \mathrm{~h}$ before an experiment (5 to $7 \mathrm{~h}$ before being placed in experimental chambers), larval fishes were removed from culture chambers, placed in aerated, filtered seawater at $24^{\circ} \mathrm{C}$, and starved until the experiment began.

Prey items. Wild zooplankton prey field: Eight to $12 \mathrm{~h}$ before an experiment, 2 microplankton nets (80 $\mu \mathrm{m}$ Nytex mesh, $0.3 \mathrm{~m}$ diameter, 3:1 aspect ratio) were deployed in the lower York River, Virginia, USA. The lower York River supports neither oyster reefs nor 
a large oyster population (Morales-Alamo \& Mann 1998), thus these plankton samples are representative of conditions at sites away from oyster reefs. Nets were oriented to face into the current such that the top of the mouth support ring was within $0.1 \mathrm{~m}$ of the surface. The microplankton collected from each net were sieved through a $202 \mu \mathrm{m}$ Nytex mesh to remove coelenterates and any larval fishes, taken to the laboratory, and held in $2 \mathrm{l}$ of filtered, well-aerated seawater in light conditions. Debris and sediment were allowed to settle out before experimental aliquots of plankton were removed. Before plankton aliquots were added to the experimental chambers, representative aliquots were examined under a dissecting microscope to verify that the plankton were alive and swimming.

Veliger prey field: Bivalve veligers were obtained from hatchery facilities at either the Virginia Institute of Marine Science (VIMS) or VIMS Eastern Shore Laboratory (ESL) at least $18 \mathrm{~h}$ before an experiment. Veligers from the VIMS Hatchery required no salinity acclimatization, whereas ESL veligers (rearing salinities of 33 to $35 \%$ ) were acclimated to lower York River salinities at a rate of 1 to $2 \%$ per $2 \mathrm{~h}$ to reach an endpoint equal to ambient York River salinities (12 to $17 \%$ ). Either Crassostrea virginica or Mercenaria mercenaria veligers were used in experiments; bivalve species were never mixed. Samples of veligers were measured to the nearest $0.01 \mathrm{~mm}$ with a computer image analysis system before experiments. Veligers were maintained in aerated, filtered seawater postacclimation and before addition to the experimental chambers. Veligers were fed algae (Isochrysis galbana or Pseudoisochrysis paradoxa) 4 to $6 \mathrm{~h}$ before experiments began.

Mixture of wild plankton and veligers: Wild plankton were supplemented with bivalve veligers to approximate field concentrations of veligers (38 oyster pediveligers $\mathrm{l}^{-1}$, Southworth 1998) observed in proximity to restored oyster reefs in Virginia (e.g. Shell Bar Reef, Great Wicomico River) during the seasonal window when larval fishes and oyster veligers co-occur in the plankton, i.e. June to July.

Experimental protocol. Feeding experiments were conducted using $150 \mathrm{ml}$ beakers as feeding chambers. Beakers were filled with $50 \mathrm{ml}$ of filtered seawater at 24 to $26^{\circ} \mathrm{C}$ and were maintained in artificial light conditions throughout experiments. Larval fishes were added to each chamber $1 \mathrm{~h}$ before prey items were added. Different concentrations of fishes and different mixtures of prey items were tested for each fish species. Larval fish (predator) concentrations were 1, 3, or 5 fishes per beaker. Fishes from each predator concentration were offered bivalve veligers (veliger), wild plankton (WP), or a mixture of wild plankton supplemented with bivalve veligers (veliger $+W P$ ).
Experiments were initiated by the addition of a $5 \mathrm{ml}$ aliquot of concentrated prey to each chamber. Wild plankton collections were combined to give total prey densities in each chamber of $>1000$ prey $^{-1}$ to ensure that food was not limiting (Connaughton 1994). These concentrations are similar to prey concentrations reported in other studies of larval fish feeding behavior (Mathias \& Li 1982, Stoecker \& Govoni 1984, Munk \& Kiørboe 1985, Mills et al. 1987, Chesney 1989).

Prey density or availability was determined by enumerating individual organisms in $5 \mathrm{ml}$ aliquots taken from experimental chambers and fixed in $70 \%$ ethanol. Fishes were allowed to feed undisturbed for $3 \mathrm{~h}$. Experiments were ended by the removal of fishes from the chambers $3 \mathrm{~h}$ after prey addition. All fish were immediately placed in 10\% neutral buffered formalin and saved for subsequent dissection and gut content analyses. Notochord length was determined to the nearest $0.01 \mathrm{~mm}$ post-preservation using an image analysis system.

Data analyses. Only fishes that had consumed at least 1 prey item were used in these analyses. The percentage of fishes feeding (Table 1) was calculated for each experimental block or predator concentration/prey type combination (e.g. 1 fish per beaker fed only veligers) by dividing the number of fish with food items in their guts by the total number of fish used in the experiment. A priori significance levels for statistical tests were $p=0.05$. Assumptions of homogeneity of variance were tested using Bartlett's test (Zar 1996) while assumptions of normality were tested with the Ryan-Joiner test (similar to ShapiroWilks per Minitab 1995). Unless otherwise noted, data satisfied both of these assumptions. Fisher's pairwise test (Zar 1996) was used as a post-hoc multiple comparison test.

Effects of predator age, predator concentration, and prey type: Total numbers of prey items consumed by each species were transformed (reciprocal transformation, Zar 1996) to meet the assumptions of homogeneity of variance and normality. The influence of predator age, predator concentration, and prey type on feeding behavior for individual species of larval fishes were evaluated with 3-factor ANOVAs (1 per species; Table 2).

Prey selectivity: Two different graphical methods were used to qualitatively describe feeding selectivity by these reef fishes. First, percentages of prey items consumed or used by each fish species were plotted against percentages of prey available in the habitat (Fig. 1) using a modification of the technique proposed by Costello (1990). Each point on the graph represents the percentage availability in the habitat and percentage consumption by fish for a specific prey taxon. Amundsen et al. (1996) recommend another graphic 
Table 1. Summary of laboratory feeding experiments to evaluate feeding preferences of larval oyster reef fishes. Bivalve veligers, wild plankton (WP), and mixtures of both were used as prey items. Treatment shows prey type and fish concentration per beaker, e.g. prey - fish concentration or Veliger -1 fish. NA: prey items not available for consumption in a particular experimental block. $\mathrm{n}$ : number of individual fish per treatment. Vel: bivalve veligers; Cop: copepods; Pol: polychaete larvae; Dia: diatoms

\begin{tabular}{|c|c|c|c|c|c|c|c|c|c|c|c|c|}
\hline \multirow{2}{*}{$\begin{array}{l}\text { Predator } \\
\text { Age } \\
\text { Treatment }\end{array}$} & \multirow[t]{2}{*}{$\mathrm{n}$} & \multirow{2}{*}{$\begin{array}{l}\text { Mean noto- } \\
\text { chord length } \\
(\mathrm{mm}) \pm \mathrm{SE}\end{array}$} & \multirow[t]{2}{*}{$\begin{array}{l}\% \text { fish } \\
\text { feeding }\end{array}$} & \multirow{2}{*}{$\begin{array}{l}\text { Mean prey } \\
\text { concentration } \\
\left(1000 \mathrm{l}^{-1}\right)\end{array}$} & \multicolumn{4}{|c|}{$\begin{array}{l}\text { Prey field composition } \\
\text { (\% of total) }\end{array}$} & \multicolumn{4}{|c|}{ Chesson's alpha } \\
\hline & & & & & Vel & Cop & Pol & Dia & Vel & Cop & Pol & Dia \\
\hline \multicolumn{13}{|l|}{ Naked goby } \\
\hline \multicolumn{13}{|l|}{$5 \mathrm{~d}$} \\
\hline Veliger - 1 fish & 6 & $3.97 \pm 0.11$ & 33 & 1 & 100 & & & & 1 & NA. & NA & NA \\
\hline WP - 1 fish & 4 & $3.78 \pm 0.09$ & 0 & 10 & 15 & 18 & 39 & 28 & - & - & - & - \\
\hline Veliger + WP - 1 fish & 6 & $3.60 \pm 0.06$ & 17 & 6 & 18 & 28 & 35 & 18 & 0.6 & 0.4 & 0 & 0 \\
\hline Veliger - 3 fish & 7 & $3.70 \pm 0.07$ & 14 & 1 & 100 & & & & 1 & NA & NA & NA \\
\hline Veliger + WP - 3 fish & 8 & $3.69 \pm 0.06$ & 25 & 4 & 20 & 22 & 35 & 22 & 1 & 0 & 0 & 0 \\
\hline \multicolumn{13}{|l|}{$15 \mathrm{~d}$} \\
\hline Veliger - 1 fish & 6 & $4.19 \pm 0.17$ & 67 & 3 & 100 & & & & 1 & NA & NA & NA \\
\hline WP - 1 fish & 5 & $4.30 \pm 0.14$ & 0 & 11 & 10 & 43 & 21 & 26 & - & - & - & - \\
\hline Veliger + WP - 1 fish & 6 & $4.16 \pm 0.06$ & 100 & 9 & 40 & 22 & 16 & 21 & 1 & 0 & 0 & 0 \\
\hline Veliger - 3 tish & 17 & $4.14 \pm 0.05$ & 53 & 3 & 100 & & & & 1 & NA & NA & NA \\
\hline WP - 3 fish & 15 & $4.07 \pm 0.05$ & 13 & 11 & 10 & 47 & 26 & 16 & 1 & 0 & 0 & 0 \\
\hline Veliger + WP - 3 fish & 14 & $4.30 \pm 0.06$ & 50 & 6 & 31 & 30 & 11 & 27 & 1 & 0 & 0 & 0 \\
\hline \multirow{2}{*}{\multicolumn{13}{|c|}{$\begin{array}{l}\text { Feather blenny } \\
3 \text { d }\end{array}$}} \\
\hline & & & & & & & & & & & & \\
\hline Veliger - 1 fish & 6 & $3.86 \pm 0.04$ & 83 & 36 & 100 & & & & 1 & NA & NA & NA \\
\hline WP - 1 fish & 6 & $3.87 \pm 0.05$ & 0 & 3 & 17 & 27 & 16 & 39 & - & - & - & - \\
\hline Veliger + WP - 1 fish & 6 & $4.02 \pm 0.08$ & 16 & 18 & 72 & 7 & 8 & 12 & 1 & 0 & 0 & 0 \\
\hline Veliger - 3 fish & 18 & $3.90 \pm 0.03$ & 30 & 29 & 100 & & & & 1 & NA & NA & NA \\
\hline WP -3 fish & 18 & $3.87 \pm 0.04$ & 28 & 7 & 12 & 26 & 24 & 38 & 0.6 & 0 & 0.2 & 0.2 \\
\hline Veliger + WP - 3 fish & 18 & $3.95 \pm 0.08$ & 56 & 22 & 72 & 10 & 6 & 11 & 0.9 & 0 & 0 & 0.1 \\
\hline Veliger - 5 fish & 25 & $3.83 \pm 0.04$ & 36 & 25 & 100 & & & & 1 & NA & NA & NA \\
\hline WP - 5 fish & 30 & $3.89 \pm 0.04$ & 10 & 6 & 20 & 26 & 23 & 31 & 0.33 & 0 & 0.67 & 0 \\
\hline Veliger + WP - 5 fish & 23 & $3.97 \pm 0.05$ & 39 & 40 & 78 & 7 & 4 & 10 & 0.70 & 0.08 & 0.11 & 0.11 \\
\hline \multicolumn{13}{|l|}{$5 \mathrm{~d}$} \\
\hline Veliger - 1 fish & 6 & $4.01 \pm 0.11$ & 67 & 10 & 100 & & & & 1 & NA & NA & NA \\
\hline WP -1 fish & 6 & $4.12 \pm 0.06$ & 33 & 5 & 36 & 18 & 20 & 26 & 0 & 0 & 1 & 0 \\
\hline Veliger + WP - 1. fish & 7 & $3.88 \pm 0.04$ & 71 & 17 & 61 & 12 & 12 & 14 & 1 & 0 & 0 & 0 \\
\hline Veliger - 3 fish & 17 & $3.96 \pm 0.05$ & 88 & 11 & 100 & & & & 1 & NA & NA & NA \\
\hline WP - 3 fish & 18 & $3.87 \pm 0.03$ & 39 & 7 & 17 & 21 & 24 & 37 & 0 & 0.38 & 0 & 0.62 \\
\hline Veliger + WP - 3 fish & 17 & $3.82 \pm 0.06$ & 76 & 9 & 60 & 16 & 0 & 24 & 0.47 & 0.05 & 0.42 & 0.06 \\
\hline Veliger - 5 fish & 20 & $3.89 \pm 0.03$ & 70 & 13 & 100 & & & & 1 & NA & NA & NA \\
\hline WP - 5 fish & 20 & $4.18 \pm 0.06$ & 35 & 7 & 0 & 27 & 17 & 56 & 0 & 0.14 & 0.71 & 0.14 \\
\hline Veliger + WP - 5 fish & 20 & $3.95 \pm 0.06$ & 70 & 20 & 70 & 8 & 8 & 14 & 0.94 & 0.00 & 0.06 & 0.00 \\
\hline \multicolumn{13}{|l|}{ Striped blenny } \\
\hline Veliger - 1 fish & 6 & $3.92 \pm 0.08$ & 33 & 3 & 100 & & & & 1 & NA & NA & $\mathrm{NA}$ \\
\hline WP -1 fish & 5 & $4.34 \pm 0.11$ & 20 & 13 & 11 & 39 & 19 & 31 & 1 & 0 & 0 & 0 \\
\hline Veliger + WP - 1 fish & 6 & $4.21 \pm 0.09$ & 33 & 12 & 33 & 30 & 16 & 21 & 0 & 1 & 0 & 0 \\
\hline Veliger - 3 fish & 16 & $4.23 \pm 0.05$ & 25 & 2 & 100 & & & & 1 & $\mathrm{NA}$ & $\mathrm{NA}$ & NA \\
\hline WP- 3 fish & 17 & $4.13 \pm 0.05$ & 29 & 11 & 9 & 49 & 13 & 29 & 0.20 & 0.44 & 0.16 & 0.20 \\
\hline Veliger + WP - 3 fish & 17 & $4.12 \pm 0.06$ & 35 & 16 & 32 & 34 & 7 & 27 & 0.53 & 0.19 & 0.28 & 0.00 \\
\hline Veliger - 5 fish & 30 & $4.12 \pm 0.03$ & 23 & 8 & 100 & & & & 1 & NA & NA & NA \\
\hline WP -5 fish & 30 & $4.15 \pm 0.04$ & 33 & 12 & 7 & 37 & 16 & 40 & 0.40 & 0.43 & 0.17 & 0.00 \\
\hline Veliger + WP - 5 fish & 30 & $4.09 \pm 0.04$ & 43 & 16 & 30 & 28 & 15 & 26 & 0.31 & 0.31 & 0.15 & 0.23 \\
\hline \multicolumn{13}{|l|}{$5 \mathrm{~d}$} \\
\hline Veliger - 1 fish & 6 & $4.46 \pm 0.11$ & 33 & 1 & 100 & & & & 1 & NA & NA & NA \\
\hline WP - 1 fish & 5 & $4.91 \pm 0.11$ & 20 & 6 & 24 & 18 & 37 & 20 & 0 & 1 & 0 & 0 \\
\hline Veliger + WP - 1 fish & 6 & $4.76 \pm 0.05$ & 50 & 10 & 41 & 14 & 24 & 21 & 0.51 & 0 & 0.49 & 0 \\
\hline Veliger - 3 fish & 9 & $4.66 \pm 0.12$ & 56 & 1 & 100 & & & & 1 & NA & NA & NA \\
\hline WP -3 fish & 17 & $4.77 \pm 0.07$ & 59 & 6 & 16 & 25 & 29 & 29 & 0.03 & 0.65 & 0 & 0.32 \\
\hline Veliger + WP - 3 fish & 18 & $4.64 \pm 0.06$ & 56 & 10 & 27 & 11 & 39 & 21 & 0.46 & 0.10 & 0.38 & 0.06 \\
\hline
\end{tabular}


Table 2. Summary of ANOVAs performed on data from laboratory feeding experiments on individual species of larval fishes - Significance at the $p=0.05$ level

\begin{tabular}{|c|c|c|c|c|}
\hline Species & Factors & df & p-value & Fisher's test \\
\hline \multirow[t]{7}{*}{ Naked goby } & Predator age & 1 & $0.02^{\circ}$ & \multirow[t]{2}{*}{$15 \mathrm{~d}>5 \mathrm{~d}$} \\
\hline & Predator concentration & 2 & 0.08 & \\
\hline & Prey type & 2 & $<0.001^{\circ}$ & \multirow{5}{*}{ Veligers, Veligers + WP $>$ WP } \\
\hline & Predator age $\times$ Predator concentration & 1 & 0.08 & \\
\hline & Predator age $\times$ Prey type & 2 & 0.15 & \\
\hline & Predator concentration $\times$ Prey type & 2 & $0.04^{\circ}$ & \\
\hline & Predator age $\times$ Predator concentration $\times$ Prey type & 2 & $0.01^{\circ}$ & \\
\hline \multirow[t]{7}{*}{ Feather blenny } & Predator age & 1 & $0.04^{*}$ & \multirow{7}{*}{ Veligers, Veligers + WP $>W P$} \\
\hline & Predator concentration & 2 & 0.82 & \\
\hline & Prey type & 2 & $0.01^{\circ}$ & \\
\hline & Predator age $\times$ Predator concentration & 2 & 0.35 & \\
\hline & Predator age $\times$ Prey type & 2 & 0.49 & \\
\hline & Predator concentration $\times$ Prey type & 4 & 0.45 & \\
\hline & Predator age $\times$ Predator concentration $\times$ Prey type & 3 & 0.91 & \\
\hline \multirow[t]{7}{*}{ Striped blenny } & Predator age & 1 & 0.06 & \\
\hline & Predator concentration & 2 & 0.66 & \\
\hline & Prey type & 2 & 0.11 & \\
\hline & Predator age $\times$ Predator concentration & 1 & $0.03^{\circ}$ & \\
\hline & Predator age $\times$ Prey type & 2 & 0.30 & \\
\hline & Predator concentration $\times$ Prey type & 4 & 0.73 & \\
\hline & Predator age $\times$ Predator concentration $\times$ Prey type & 2 & 0.35 & \\
\hline
\end{tabular}

method that relies on the variable prey-specific abundance which they suggest provides a more detailed diet description when plotted against the frequency of occurrence of a prey item. Prey-specific abundance is calculated as follows (Amundsen et al. 1996):

$$
P_{i}=\left(S_{i} / S_{t_{i}}\right) \times 100
$$

where $P_{i}=$ prey-specific abundance of prey taxon $i$; $S_{i}=$ number of prey taxon $i$ in the stomach; and $S_{t_{l}}=$ total stomach contents in only those predators with prey taxon $i$ in their stomachs. Prey-specific abundances for the 3 predator species used in this study were calculated for bivalve veligers and plotted against the percent availability of veligers in the habitat for experimental trials with wild plankton or wild plankton supplemented with veligers (Fig. 1).

Chesson's alpha was used to quantitatively describe feeding selectivity by fishes when multiple prey types were offered (Table 1). Chesson's alpha (Chesson 1978) ranges from 1 (exclusive ingestion) to 0 (complete avoidance). Relative preference for a prey type in relation to other available prey types is inherent in the calculated alpha values. Chesson's alpha is calculated using:

$$
\text { alpha }=\frac{r_{t}}{n_{i}}\left(\sum_{\lrcorner=1}^{m} \frac{r_{i}}{n_{i}}\right)^{-1}
$$

where $r_{i}=$ portion of prey taxon $i$ in the ingested food; $n_{l}=$ portion of prey taxon $i$ available in the habitat; and $m=$ number of prey taxa considered .

\section{RESULTS}

\section{Preliminary laboratory feeding experiments to determine gut residence time}

Gut residence time was greater than $3 \mathrm{~h}$ for all ages of blennies and types of prey items; naked gobies were assumed to have similar residence times. Gobies were not tested explicitly because they were much harder to culture and all live fishes were needed to ensure adequate replication in feeding experiments. Fish age ranged from 2 through $31 \mathrm{~d}$ and length ranged from 2.8 to $15 \mathrm{~mm}$. Although the $31 \mathrm{~d}$ old fishes were post-settlement and, by definition, no longer larvae, they were included in these experiments to ensure an adequate size range of animals for accurate determinations of gut residence time. All fishes were fed the prey items on which they had been cultured and $>90 \%$ of the fishes tested were feeding during the window when prey were offered.

\section{Multifactorial laboratory feeding experiments}

Effects of predator age, predator concentration, and prey type

Predator age significantly affected feeding behavior of naked gobies and feather blennies (ANOVAs, p < 0.05 ; Table 2 ). Older fishes consumed more prey items 
- Bivalve veligers - Copepods

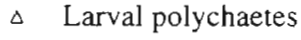

$\nabla \quad$ Diatoms
- Prey-specific veliger abundance
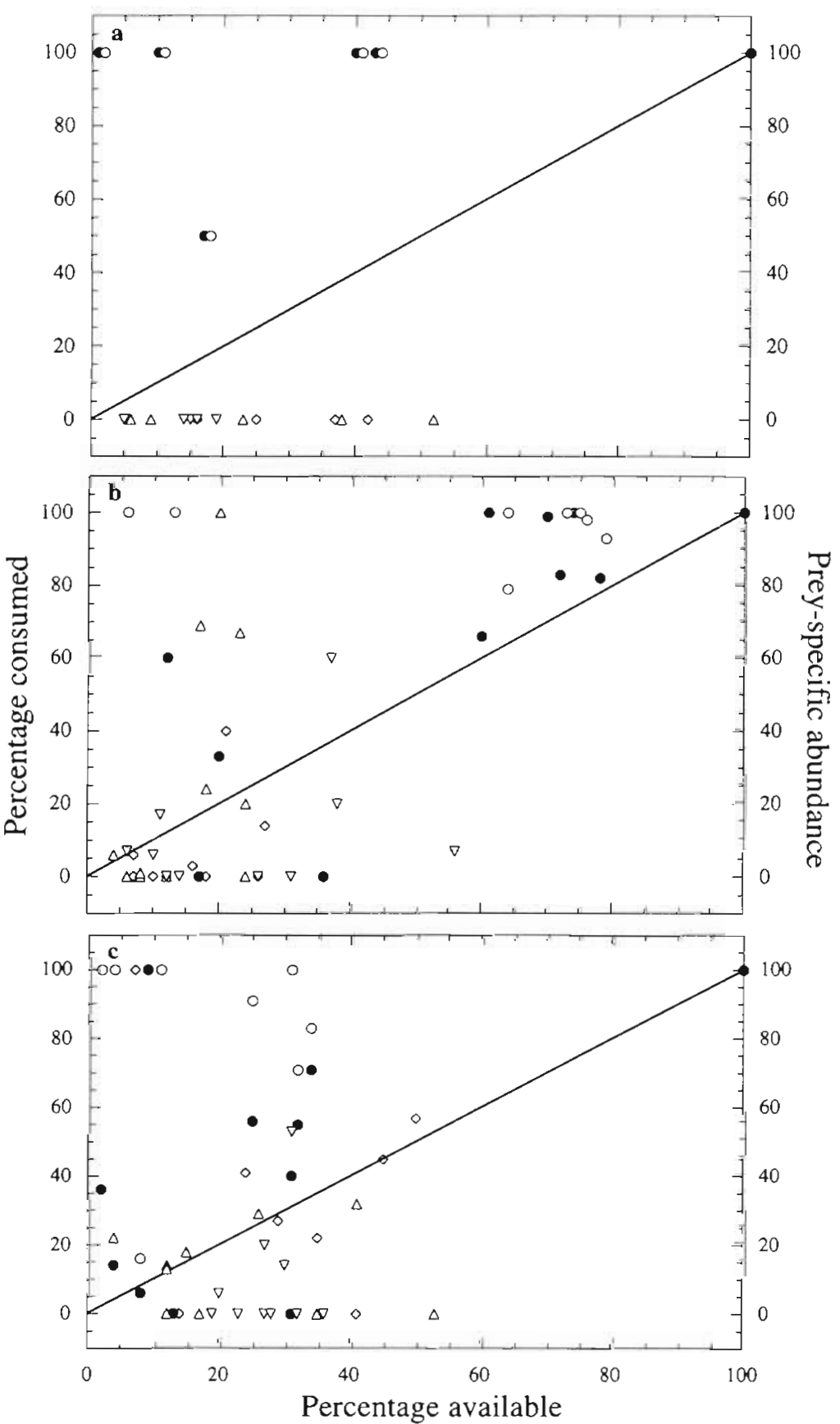

Fig. 1. Percentage consumption of prey items and prey-specific veliger abundance plotted in relation to percentage availability for laboratory feeding experiments with (a) naked gobies $(n=32)$, (b) feather blennies $(n=157)$. and (c) striped blennies $(n=82$ ). Points above the diagonal line indicate prey items that are consumed at a higher proportion than their availability in the plankton. In cases where points representing percent bivalve veligers consumed overlapped completely with points for prey-specific veliger abundances, percent bivalve veliger abundance points were offset $1 \mathrm{x}$-axis unit (a percentage point) to the left and prey-specific veliger abundance points were offset $1 x$-axis unit to the right than younger fishes in the case of both naked gobies ( 15 vs $5 \mathrm{~d}$ old) and feather blennies ( 5 vs $3 \mathrm{~d}$ old).

Predator concentration did not significantly affect the total number of prey consumed by any larval fish species. Total prey consumption by naked gobies and feather blennies was significantly affected by the type of prey offered (ANOVAs, p < 0.05 ; Table 2). Bivalve veligers and veliger-supplemented wild plankton were consumed by naked gobies and feather blennies at significantly higher rates than were wild plankton. The interactions between prey type and predator concentration and prey type, predator concentration, and predator age were significant for naked gobies (ANOVA, $\mathrm{p}<0.05$; Table 2).

\section{Prey selectivity}

Larval reef fishes selectively consumed bivalve veligers from mixed prey fields. This preference is demonstrated both qualitatively (Fig. 1) and quantitatively (selectivity index values; Table 1). Specialization on a diet item is indicated graphically by points with low availability and high consumption (Costello 1990). Naked gobies showed strong preferences for bivalve veligers, regardless of their availability (Table 1, Fig. 1).

The average percentage of feeding naked goby larvae increased with age. At $5 \mathrm{~d}, 18 \%$ of the larvae fed; at $15 \mathrm{~d}, 47 \%$ of naked goby larvae fed (Table 1). The range of prey items consumed by gobies during these experiments was 1 to 7 individual prey. Feeding naked gobies preferred veligers when offered a mix of veligers and wild plankton at both predator concentrations (Table 1).

The average percentage of feeding 3 and $5 \mathrm{~d}$ old feather blenny larvae was 36 and $59 \%$, respectively (Table 1). Feather blennies preferentially consumed bivalve veligers at veliger concentrations as low as $12 \%$ of the available prey field $(3 \mathrm{~d}$ old, WP- 3 fish). The maximum number of prey items consumed by an individual feather blenny, or an individual fish of any species, during the $3 \mathrm{~h}$ experimental window was 24 Crassostrea virginica veligers by a $5 \mathrm{~d}$ old blenny. Within the same 
cohort of fish larvae during the 3 h experiment, 2 other blennies consumed 9 prey items each and a third ate 14 different prey items. Three day old feather blennies preferred veligers in all but 1 trial; larval polychaetes were preferred when wild plankton was offered at densities of 5 fish chamber ${ }^{-1}$ (Table 1 ). When veligers supplemented wild plankton, veligers were strongly preferred prey for feather blennies of both ages (Table 1). Five day old feather blenny larvae did not consume veligers in wild plankton experiments perhaps due to relatively low veliger availability (Table 1).

For striped blennies, the average percentage of feeding fish was $30 \%$ for the 2 d old larvae and $46 \%$ for the $5 \mathrm{~d}$ old larvae (Table 1). The number of prey consumed by an individual striped blenny during the experiments ranged from 1 to 6 prey. When veligers were offered as the exclusive prey item, they were consumed at all predator densities by both 2 and $5 \mathrm{~d}$ old larvae. Striped blennies consumed bivalve veligers preferentially at concentrations as low as $11 \%$ of the available prey field ( $2 \mathrm{~d}$ old, WP - 1 fish). When offered wild plankton, copepods or larval polychaetes were preferred over veligers at most predator concentrations, possibly reflecting relatively low availability of veligers in wild plankton (Table 1). When wild plankton supplemented with veligers was offered to striped blennies, veligers were selected for in all cases but one (2 d old; veliger + WP - 1 fish) where copepods were consumed exclusively (Table 1).

\section{DISCUSSION}

Larval reef fishes fed selectively on bivalve veligers in multi-factorial laboratory experiments. Diet preferences for veligers were demonstrated using qualitative (Fig. 1) and quantitative methods (e.g. selectivity indices, Table 1). These feeding patterns indicate selection for and specialization on bivalve veligers by all 3 species of larval fishes (Costello 1990, Amundsen et al. 1996). Low preference for veligers indicated by the Chesson's alpha values may be an artifact of relatively low veliger availability (Table 1) rather than active 'rejection'.

Feeding behavior of these fishes was significantly affected by age; older fishes consumed more prey items than younger fishes. Olney (1996) reports similar feeding patterns for seaboard gobies Gobiosoma ginsburgi. Predator concentration did not have a significant effect on larval goby and blenny feeding behavior in these experiments. Experimental chamber dimensions and volume $(0.15 \mathrm{l})$ were small enough that any potential benefits offered by schooling behavior for prey location were probably negligible. Conversely, feeding behavior may have been inhibited by lack of schooling opportunities. Demersal naked gobies have been observed schooling directly above shell substrate or other structures immediately prior to settlement (Breitburg 1989). Behavior of planktonic goby and blenny larvae in relation to conspecifics is unknown. Predator concentrations in the chambers may not have been high enough $(1,2,3$, and 5 fishes) to cause competitive responses among individuals, especially in light of the high availability of food items.

Total prey concentrations were $>1000$ prey $^{-1}$ for all experiments to ensure that food was not limiting. Connaughton (1994) established 1000 prey $^{-1}$ as a threshold value at which the maximum number of weakfish Cynoscion regalis larvae had food occurring in their guts and above which consumption did not significantly increase even with an order of magnitude increase in prey availability. Natural plankton distributions are patchy (e.g. Wiebe 1970, Houde \& Lovdal 1985, Owen 1989, Genin et al. 1994). Wild plankton abundance estimates may vary across several orders of magnitude depending upon the species of interest and the measurement scales used (e.g. Wiebe 1970, Gallager et al. 1996). Local concentrations of 1500 to 2000 Pleuromamma gracilis $\mathrm{l}^{-1}$ (Sixtymile Bank, CA; Genin et al. 1994), >181000 Calanus sp. l $^{-1}$ (St. Margaret's Bay, Nova Scotia; Sameoto 1975), and 600000 Limacina retroversa l $^{-1}$ (Great South Channel, Georges Bank; Gallager et al. 1996) have been recorded. Houde $\&$ Lovdal (1985) report concentration ranges of 31.9 to 184.4 copepod nauplii $\mathrm{I}^{-1}, 6.7$ to 916.2 tintinnids $\mathrm{l}^{-1}$, and 0.6 to 9.7 mollusc veligers $1^{-1}$ for Biscayne Bay, FL. Olney (1996) provides similar mean density estimates for copepod nauplii (4.6 to $69.2 \mathrm{l}^{-1}$ ) and bivalve larvae (0.1 to $8.3 \mathrm{I}^{-1}$ ) from the Chesapeake Bay plume. Southworth (1998) reports oyster pediveliger concentrations of up to $38 \mathrm{l}^{-1}$ near Shell Bar Reef, Great Wicomico River, VA, and estimates that pediveligers composed approximately $10 \%$ of the total prey field $(\mathrm{M}$. Southworth pers. comm.). Although the small-scale prey abundances experienced by goby and blenny larvae in the field are unknown, it is reasonable to suggest that they may encounter differences in total prey abundance encompassing several orders of magnitude during development. In light of the natural variability observed in plankton abundances, 1000 total prey $\mathrm{I}^{-1}$ is a concentration threshold for optimal feeding (Connaughton 1994) as well as a reasonable representation of 'patch' abundances.

The prey items used in these experiments were small enough to be vulnerable to predation by larval reef fishes. Prey size in relation to larval fish mouth width or gape strongly influences consumption of any prey items (Hunter 1981). If a prey item is larger in all dimensions than the mouth width or height (gape) of a potential predator, its chances of being successfully captured by 
that predator are small. The veligers and a large portion of wild plankton used herein were within the range of prey widths vulnerable to predation from these fishes (i.e. 0.08 to $0.3 \mathrm{~mm}$, depending on the fish size).

Previous experience with a prey item, or habituation (Checkley 1982, Mills et al. 1987, Connaughton \& Epifanio 1993), may also affect larval fish feeding success. None of the fishes used in these experiments had been previously exposed to either veligers or a mixture of prey types. Both Connaughton \& Epifanio (1993) and Mills et al. (1987) found that habituation to a familiar prey type affects laboratory feeding results, depending on predator age and prey size. Gobies and blennies used in this study were cultured exclusively on rotifers and, subsequently, for the 15 d old naked gobies, Artemia sp. nauplii, effectively removing habituation to a particular experimental prey type as a potential source of experimental bias.

As visual predators, larval fishes feed during daylight when they are most likely to have a higher proportion of successful prey encounters. Variations in incident light have been correlated with reduced growth rates and/or feeding efficiency for bream Abramis brama (Townsend \& Risebrow 1982), striped bass Morone saxatilis (Chesney 1989), and herring Clupea harengus (Batty 1987, Batty et al. 1990). Experimental chamber shape may have an effect on fish perception of prey. Bending of light through chamber corners may change perception and, subsequently, searching behavior for those fishes that rely on the dark background outside Snell's window to highlight prey (Janssen 1981). Since these experiments were conducted in full light conditions using round chambers, visual conditions were appropriate for successful predation by larval fishes.

Morphologically and behaviorally, bivalve veligers are vulnerable to predation by larval fishes. Capture success with regard to a particular prey type is a function of both predator perception and ease of handling (Hunter 1981). Bivalve veligers move slowly in the vertical plane, either actively swimming or passively sinking (Mann \& Wolf 1983, Mann et al. 1991). The smooth rounded veliger morphology may make capture relatively simple for a larval fish as compared to ingestion of a prey item with multiple protruding appendages or more active swimming patterns (e.g. copepod nauplii, Van Duren \& Videler 1995; or polychaete larvae, Mileikovsky 1973). As larval fishes grow and develop, they may become better suited to capture more active prey items.

High degrees of feeding specialization in fishes have been correlated with narrow niche width (Amundsen et al. 1996). While ontogeny of feeding behavior in naked gobies, feather blennies, and striped blennies may eventually reduce these high levels of specializa- tion, in the earliest 'critical' period of larval development high abundances of preferred prey items (veligers) would facilitate growth. Larval fishes that have higher growth rates will settle more quickly thus escaping or avoiding potential larval stage mortality sources, e.g. starvation and predation (Shepherd \& Cushing 1980). Selective feeding by larval reef fishes on bivalve veligers may be an important mechanism by which larval reef fishes reduce the length of their larval planktonic phase and, consequently, increase recruitment success.

Acknowledgements. Support for this project was provided by a Virginia Institute of Marine Science/School of Marine Science (VIMS/SMS) Minor Research Grant and the U.S. Environmental Protection Agency Chesapeake Bay Program (CB993267-02-1). J. Govoni (NOAA/NMFS Southeast Fisheries Center, Beaufort, NC) provided the initial rotifer stock culture. D. Fridley, M. Lara, and M. Vogelbien provided valuable information on algal and rotifer culture methods. Veligers were obtained with the help of $D$. Bonniwell. $A$. Curry, V. Harmon, M. Luckenbach, and K. Simmons. R. Mann and J. Govoni offered many helpful experimental design suggestions. D. Evans, J. Govoni, M. Luckenbach, J. Olney, M. Patterson, and R. Mann provided valuable comments on earlier versions of this manuscript. This work was completed in partial fulfillment of the requirements for a doctoral dissertation from VIMS/SMS, College of William and Mary. Contribution No. 2182 from the Virginia Institute of Marine Science, College of William and Mary.

\section{LITERATURE CITED}

Amundsen PA, Gabler HM, Staldvik FJ (1996) A new approach to graphical analysis of feeding strategy from stomach content data-modification of the Costello (1.990) method. J Fish Biol 48:607-614

Batty RS (1987) Effect of light intensity on activity and food searching of larval herring, Clupea harengus: a laboratory study. Mar Biol 94:323-327

Batty RS, Blaxter JHS, Richard JM (1990) Light intensity and feeding behavior of herring, Clupea harengus. Mar Biol $107: 383-388$

Breitburg DL (1989) Demersal schooling prior to settlement by larvae of the naked goby. Environ Biol Fish 26:97-1.03

Breitburg DL (1991) Settlement patterns and presettlement behavior of the naked goby, Gobiosoma bosci, a temperate oyster reef fish. Mar Biol 109:213-221

Checkley DM Jr (1982) Selective feeding by Atlantic herring (Clupea harengus) larvae on zooplankton in natural assemblages. Mar Ecol Prog Ser 9:245-253

Chesney EJ Jr (1989) Estimating the food requirements of striped bass larvae, Morone saxatilis: effects of light, turbidity, and turbulence. Mar Ecol Prog Ser 53:191-200

Chesson J (1978) Measuring preference in selective predation. Ecology 59:211-215

Connaughton VP (1994) Selective feeding by larval weakfish, Cynoscion regalis: the influence of prey characteristics and larval behavior. $\mathrm{PhD}$ dissertation, University of Delaware, Newark

Connaughton VP, Epifanio CE (1993) Influence of previous experience on the feeding habits of larval weakfish, Cynoscion regalis. Mar Ecol Prog Ser 101:237-241 
Costello MJ (1990) Predator feeding strategy and prey importance: a new graphical analysis. J Fish Biol 36:261-263

Cowan J, Birdsong R (1985) Seasonal occurrence of larval and juvenile fishes in a Virginia Atlantic coast estuary with emphasis on drums (Family Sciaenidae). Estuaries 8: $48-59$

Dahlberg MD, Conyers JC (1973) An ecological study of Gobiosoma bosci and G. ginsburgi (Pisces, Gobiidae) on the Georgia coast. Fish Bull US 71:279-287

Gallager SM, Davis CS, Epstein AW, Solow A, Beardsley RC (1996) High-resolution observations of plankton spatial distributions correlated with hydrography in the Great South Channel, Georges Bank. Deep-Sea Res II 43: $1627-1633$

Genin A, Green C, Haury L, Wiebe P, Gal G, Kaartvedt S, Meir E, Fey C, Dawson J (1994) Zooplankton patch dynamics: daily gap formation over abrupt topography. Deep-Sea Res I 41:941-951

Govoni JJ, Ortner PB, Al-Yamani F, Hill LC (1986) Selective feeding of spot, Leiostomus xanthurus, and Atlantic croaker, Micropogonias undulatus, larvae in the northern Gulf of Mexico. Mar Ecol Prog Ser 28:175-183

Houde ED (1989) Comparative growth, mortality, and energetics of marine fish larvae: temperature and implied latitudinal effects. Fish Bull US 87:471-495

Houde ED, Lovdal JA (1984) Seasonality of occurrence, foods and food preferences of ichthyoplankton in Biscayne Bay, Florida. Estuar Coast Shelf Sci 18:403-419

Houde ED, Lovdal JA (1985) Patterns of variability in ichthyoplankton occurrence and abundance in Biscayne Bay, Florida. Estuar Coast Shelf Sci 20:79-103

Houde ED, Schekter RC (1980) Feeding by marine fish larvae: developmental and functional responses. Environ Biol Fish 5:315-334

Hunter JR (1981) Feeding ecology and predation of marine fish larvae. In: Lasker R (ed) Marine fish larvae: morphology, ecology, and relation to fisheries. Washington Sea Grant Program, University of Washington, Seattle, WA, p 33-77

Janssen $J$ (1981) Searching for zooplankton just outside Snell's window. Limnol Oceanogr 26:1168-1171

Lindberg JC, Doroshov SI (1986) Effect of diet switch between natural and prepared foods on growth and survival of white sturgeon juveniles. Trans Am Fish Soc 115:166-171

Mann R, Wolf C (1983) Swimming behavior of larvae of the acean quahog Arctica islandica in response to pressure and temperature. Mar Ecol Prog Ser 13:211-218

Mann R, Campos B, Luckenbach M (1991) Swimming rate and responses of larvae of 3 mactrid bivalves to salinity discontinuities. Mar Ecol Prog Ser 68:257-269

Mathias JA, Li S (1982) Feeding habits of walleye larvae and juveniles: comparative laboratory and field studies. Trans Am Fish Soc 111:722-735

Editorial responsibility: Diane Stoecker (Contributing Editor), Cambridge, Maryland, USA
Mileikovsky SA (1973) Speed of active movement of pelagic larvae of marine bottom invertebrates and their ability to regulate their vertical position. Mar Biol 23:11-17

Mills EL, Widzowski DV, Jones SR (1987) Food conditioning and prey selection by young yellow perch (Perca flavens). Can J Fish Aquat Sci 44:549-555

Minitab (1995) Minitab 10Xtra user's guide. Minitab Inc, State College, PA

Morales-Alamo R, Mann R (1998) The status of Virginia's public oyster resource 1997 Virginia Institute of Marine Science, Gloucester Point, Virginia Marine Resource Report 98-2

Munk P, Kiørboe T (1985) Feeding behavior and swimming activity of larval herring (Clupea harengus) in relation to density of copepod nauplii. Mar Ecol Prog Ser 24:15-21

Olney JE (1996) Community structure, small scale patchiness, transport, and feeding of larval fishes in an estuarine plume. PhD dissertation, University of Maryland, College Park

Owen RW (1989) Microscale and finescale variations of small plankton in coastal and pelagic environments. J Mar Res $47: 197-240$

Sameoto DD (1975) Tidal and diurnal effects of zooplankton sample variability in a nearshore marine environment. J Fish Res Board Can 32:347-366

Shenker JM, Hepner DJ, Frere PE, Currence LE, Wakefield WW (1983) Upriver migration and abundance of naked goby (Gobiosoma bosci) larvae in the Patuxent River estuary, Maryland. Estuaries 6:36-42

Shepherd JG, Cushing DH (1980) A mechanism for density dependent survival of larval fish as the basis for a stockrecruitment relationship. Cons Int Explor Mer J 39: 160-167

Southworth MJ (1998) Oyster reef broodstock enhancement in the Great Wicomico River, Virginia. MS thesis, Virginia Institute of Marine Science/School of Marine Science, College of William and Mary, Williamsburg, VA

Stoecker D, Govoni JJ (1984) Food selection by young larval gulf menhaden (Brevoortia patronus). Mar Biol 80: 299-306

Townsend CR, Risebrow AJ (1982) The influence of light level on the functional response of a zooplanktivorous fish. Oecologia 53:293-95

Van Duren L, Videler J (1995) Swimming behavior of developmental stages of the calanoid copepod Temora longicornis at different food concentrations. Mar Ecol Prog Ser 126:153-161

Wells HW (1961) The fauna of oyster beds, with special reference to the salinity factor. Ecol Monogr 31:239-266

Wiebe PH (1970) Small-scale spatial distribution in oceanic zooplankton. Limnol Oceanogr 15:205-217

Zar JH (1996) Biostatistical analysis, 3rd edn. Prentice Hall, Upper Saddle River, NJ

Submitted: March 2, 1998; Accepted: November 20, 1998

Proofs received from author(s): March 23, 1999 